\title{
Conservative treatment for Brucella testicular abscesses: A case report and literature review
}

\author{
Sakher Tahaineh, MD; Rawan Abu Mughli, MD; Hanan I Hakami, MD;: Mohamad I Al-Faham, MD*
}

*Department of Urology, Security Forces Hospital, Makkah, Saudi Arabia; *Department of Radiology, Security Forces Hospital, Makkah, Saudi Arabia; ${ }^{\circledR}$ Section of Infectious Diseases, Department of Medicine, Security Forces Hospital, Makkah, Saudi Arabia

Cite as: Can Urol Assoc J 2015;9(9-10):E679-82. http://dx.doi.org/10.5489/cuaj.2669 Published online September 9, 2015.

\section{Abstract}

Brucellosis is a multi-organ infectious disease that can cause genitourinary manifestations..$^{1-4}$ The most common genitourinary manifestation is orchitis, ${ }^{2,4}$ however, intratesticular abscesses are a rare complication. Although surgery is the standard treatment for intratesticular abscesses, medical therapy alone can be successful. We report the case of a 36-year-old man with multiple testicular abscesses caused by relapse of systemic brucellosis. The patient presented after a history of treated systemic brucellosis with left testicular swelling and pain. An ultrasound showed multiple small testicular abscesses, and the repeat diluted brucella titer demonstrated the causative pathogen. The patient was successfully treated with 3 months of oral targeted antibiotics, with no need for drainage or orchiectomy.

\section{Introduction}

Brucellosis is a multi-organ infectious disease that can cause genitourinary manifestations. ${ }^{1-4}$ Testicular abscesses are a rare complication. Although surgery is the standard treatment, medical therapy alone can be successful. We report a case of a 36-year-old man with multiple testicular abscesses caused by relapse of systemic brucellosis, and provide a literature review.

\section{Case report}

A 36-year-old man presented to the emergency department with left testicular pain of 6 weeks duration that increased in severity in the previous few days. His medical history was insignificant, except for systemic Brucella infection in the form of fever and rigors after ingestion of raw milk, treated 3 months ago.

On physical examination, the left hemi-scrotum was tender and swollen. No fever was documented. Laboratory studies, including complete blood count, kidney function tests, urine analysis and subsequent urine culture, were normal. The patient was suspected to have epididymo-orchitis. Consequently, scrotal ultrasound was performed, which revealed a swollen left testis with multiple parenchymal irregular anechoic cystic areas with thin internal septation. The overall vascularity of the left testis increased (Fig. 1). The right testis and both epididymides were normal. These radiological findings were suspicious for testicular abscesses.

In view of patient's history of Brucella, a possible relapse of Brucellosis in the form of testicular abscesses was proposed. While awaiting the opinion of the infectious team, the patient was administered ceftriaxone. Fine-needle aspiration was discussed with the radiology team, but was deemed unsuitable due to the multiplicity and small size of abscesses. We discussed with the patient the option of intraoperative drainage and possible partial orchiectomy, but he was reluctant. Accordingly, we started a trial of conservative therapy.

Further analysis, including blood culture, brucella titers and purified protein derivative (PPD) test for tuberculosis, were negative. However, because of the high index of suspicion of relapse of Brucellosis, a repeat of Brucella titer using a dilution of agglutination of Brucella was done. This was positive for brucella Melitensis, titer $=1: 320$ (normal less than 1:80). Therefore, treatment changed to doxycycline $100 \mathrm{mg}$ orally twice daily, ciprofloxacin $500 \mathrm{mg}$ orally twice daily, and sulfamethoxazole and trimethoprim $960 \mathrm{mg}$ orally twice daily for 2 weeks.

At the 1-week follow-up, the patient showed significant improvement clinically and some improvement sonographically. Hence, he was continued on the same treatment, and advised to follow-up after 2 weeks. At that time, the ultrasound was repeated and it showed marked reduction in the size of the abscesses as the largest one measured $4 \mathrm{~mm}$ in diameter (Fig. 2).

At the 6-week follow-up, the patient was doing well with complete resolution of his symptoms. 


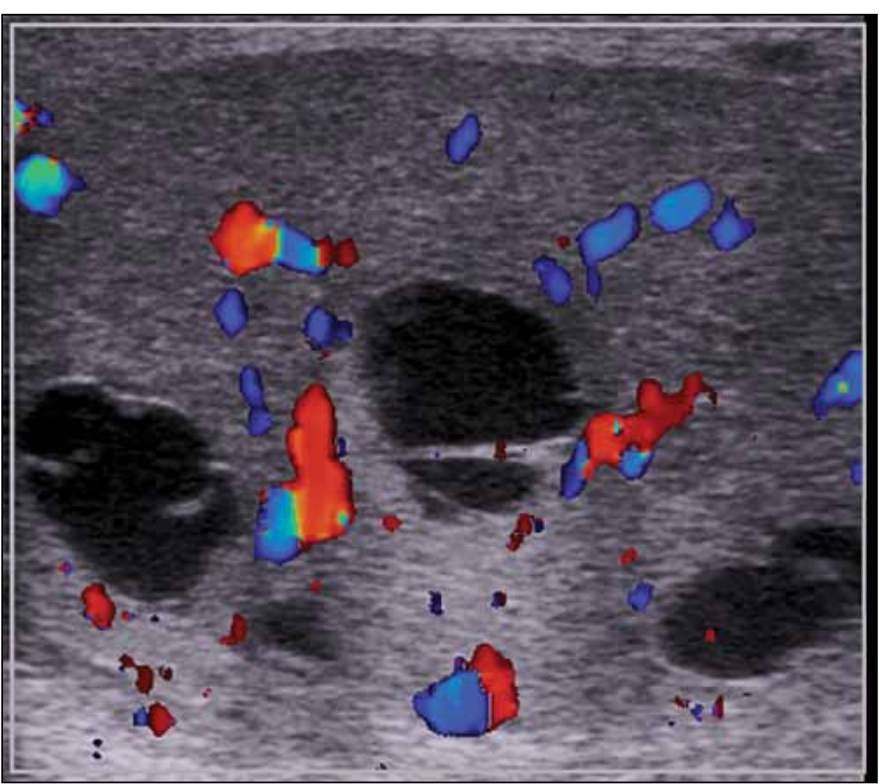

Fig. 1. An image showing the increase in the overall vascularity of the left testis.

\section{Discussion}

This case documents the diagnosis of multiple testicular abscesses caused by Brucella species. The patient presented after a history of treated systemic Brucellosis with left testicular swelling and pain. An ultrasound revealed multiple small testicular abscesses, and the repeat diluted Brucella titer showed the causative pathogen. The patient was successfully treated with 3 months of oral targeted antibiotics, with no need for drainage or orchiectomy.

Brucellosis is a multi-organ infectious disease that is considered endemic in Mediterranean, ${ }^{1,3,5-7}$ the Arabian gulf, and parts of Mexico, Central and South America. ${ }^{7}$ It is caused by 4 Brucella species; B. abortus, B. melitensis, B. uis, and B. canis. ${ }^{2}$ Brucella melitensis is the most common one, ${ }^{3,4}$ which is concordant with the pathogen in our case. Direct contact with infected animals or ingestion of contaminated animal products are the main routes of human transmission..$^{1-3}$ The most common clinical findings are fever and osteoarticular involvement. ${ }^{1}$ Genitourinary involvement in endemic areas ranges between $1.6 \%$ and $20 \% .^{2-4}$ The most common genitourinary manifestation is orchitis; ${ }^{2,4}$ however, intratesticular abscess is a rare complication.

A literature review revealed 9 cases of testicular abscesses caused by Brucella, 6 of which ended with orchiectomy, ${ }^{3,4,8-11}$ while 2 needed drainage. ${ }^{1,5}$ Only 1 case was treated by medical therapy alone ${ }^{6}$ (Table 1 ). In most cases, there was relevant history that guided the clinician to think of Brucella as the causative pathogen. Moreover, imaging played an essential role in the diagnosis.

In acute Brucellosis cases, positive blood cultures are obtained in only $10 \%$ to $30 \%$ of cases and positivity decreases with increased duration of illness. Therefore, most cases are diagnosed by standard tube agglutination test. In chronic localized Brucellosis, standard tube agglutination test titers may be low due to prozone phenomenon which indicates the presence of immunoglobulin $A$ and $\mathrm{G}$ blocking antibodies. ${ }^{3}$ This happened in our case, so we relied on the dilution tests to confirm our suspicion. Brucella testicular abscesses can be diagnosed by the presence of related history, sonographic features of abscess, and serology.

In previously reported cases, orchiectomy was done either due to suspicion of tumour, or failed medical management. Even though the abscesses in those cases were larger than our case, we still think that medical treatment should be tried initially, particularly if the patient showed clinical improvement. The one patient treated by medical therapy alone also had a large abscess. ${ }^{6}$ Although he improved clinically on subsequent follow-up, the abscess increased in size. Consequently, he was planned for orchiectomy, which he refused and returned 5 months later with regression of his abscess. ${ }^{6}$

Medical treatment is recommended for at least 6 weeks. Combined antibiotics, such as doxycycline, rifampicin, tetracycline, ciprofloxacin, and streptomycin, were described in the treatment of Brucella infections, ${ }^{1,3,6}$ with rifampicin and deoxycycline being the preferred combination. ${ }^{6}$ We used doxycycline, ciprofloxacin and bactrim since our patient was treated earlier with doxycycline and rifampicine for his systemic Brucellosis. Our patient showed marked improvement with antibiotic therapy, so we continued with oral therapy and avoided unnecessary orchiectomy.

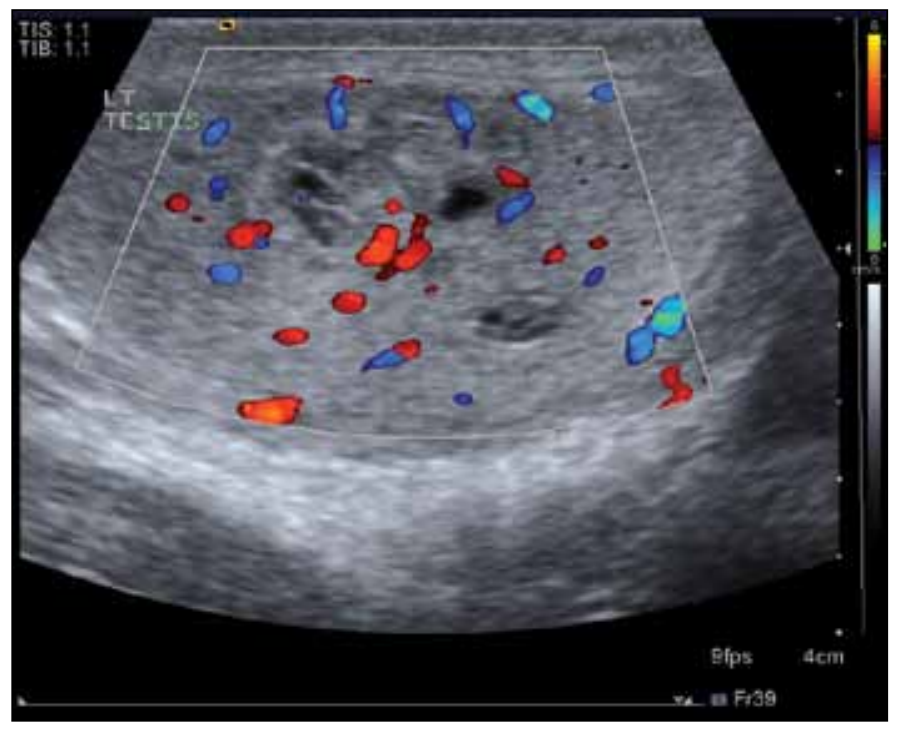

Fig. 2. A repeat ultrasound showing a marked reduction in the size of the abscesses. 


\section{Conclusion}

Brucella as a case of testicular abscess/abscesses should be suspected in patients from endemic areas, or in patients with relevant history. Successful treatment can be achieved by medical therapy alone, if the patient shows improvement clinically and sonographically - avoiding drainage and orchiectomy.
Competing interests: The authors all declare no competing financial or personal interests.

This paper has been peer-reviewed.

Table 1. Characteristics of the patients with Brucella testicular abscesses

\begin{tabular}{|c|c|c|c|c|c|c|c|c|}
\hline Reference & $\begin{array}{r}\text { Age } \\
\text { (yr) }\end{array}$ & $\begin{array}{c}\begin{array}{c}\text { Duration } \\
\text { of } \\
\text { symptoms }\end{array} \\
\text { symptom }\end{array}$ & $\begin{array}{l}\text { Clinical } \\
\text { features }\end{array}$ & $\begin{array}{c}\text { Relevant } \\
\text { history }\end{array}$ & $\begin{array}{l}\text { Brucella } \\
\text { agglutinin } \\
\text { titer }\end{array}$ & $\begin{array}{l}\text { Blood } \\
\text { culture }\end{array}$ & Ultrasound findings & Treatment \\
\hline Kaya et al. ${ }^{1}$ & 23 & 2 months & $\begin{array}{l}\text { Right } \\
\text { testicular } \\
\text { swelling }\end{array}$ & $\begin{array}{c}\text { Recent } \\
\text { ingestion of } \\
\text { unpasteurized } \\
\text { cheese }\end{array}$ & Positive & Negative & $\begin{array}{l}\text { Thick-walled abscess } \\
\text { measured } 31 \times 41 \times \\
74 \text { mm replacing the } \\
\text { entire testis }\end{array}$ & $\begin{array}{l}\text { D and S for } 7 \text { days; } \\
\text { abscess size did } \\
\text { not change; it was } \\
\text { drained, followed by } \\
D \text { and } R \text { for } 6 \text { weeks }\end{array}$ \\
\hline $\begin{array}{l}\text { Kocak et } \\
\text { al. }^{3}\end{array}$ & 32 & 2 months & $\begin{array}{l}\text { Left painless } \\
\text { testicular } \\
\text { mass }\end{array}$ & $\begin{array}{l}\text { History of } \\
\text { systemic } \\
\text { brucellos-is } 3 \\
\text { years earlier }\end{array}$ & positive & Not done & $\begin{array}{c}\text { Hypoechoic } \\
\text { heterogeneous } \\
\text { intratesticular mass } \\
\text { measured } 63 \times 42 \times \\
38 \mathrm{~mm}\end{array}$ & $\begin{array}{c}\text { Orchiectomy } \\
\text { as tumour was } \\
\text { suspected, then C } \\
\text { and D for } 6 \text { weeks }\end{array}$ \\
\hline $\begin{array}{l}\text { Akinci et } \\
\text { al. }^{4}\end{array}$ & ND & ND & ND & ND & positive & ND & Testicular abscess & $\begin{array}{c}\text { Orchiectomy and } \\
\text { antibiotic therapy for } \\
6-8 \text { weeks }\end{array}$ \\
\hline Koc et al. ${ }^{5}$ & 42 & 6 weeks & $\begin{array}{l}\text { Right } \\
\text { testicular pain } \\
\text { and swelling } \\
\text { with fever and } \\
\text { night sweats }\end{array}$ & $\begin{array}{l}\text { Ingestion of } \\
\text { unpasteurized } \\
\text { cheese }\end{array}$ & Positive & $\begin{array}{l}\text { Positive B. } \\
\text { melitens-is }\end{array}$ & $\begin{array}{l}\text { Thick walled abscess } \\
\text { measured } 55 \times 50 \times \\
40 \mathrm{~mm}\end{array}$ & $\begin{array}{l}\text { Abscess drained } \\
\text { then treated with } D \\
\text { and } R \text { for } 4 \text { months }\end{array}$ \\
\hline $\begin{array}{l}\text { Yemisen } \\
\text { et al. }{ }^{6}\end{array}$ & 42 & 2 weeks & $\begin{array}{l}\text { Right } \\
\text { testicular pain } \\
\text { and swelling } \\
\text { with fever }\end{array}$ & $\begin{array}{l}\text { Works as a } \\
\text { teacher in } \\
\text { small Turkish } \\
\text { village }\end{array}$ & Positive & negative & $\begin{array}{l}\text { Hypoechoic cystic } \\
\text { lesion measured } 20 \\
\times 15 \mathrm{~mm}\end{array}$ & $D$ and $R$ for 6 weeks \\
\hline $\begin{array}{l}\text { González } \\
\text { Sánchez et } \\
\text { al. }{ }^{7}\end{array}$ & ND & ND & $\begin{array}{l}\text { Left testicular } \\
\text { pain and } \\
\text { swelling }\end{array}$ & $\begin{array}{l}\text { History of } \\
\text { systemic } \\
\text { Brucellosis } 4 \\
\text { months earlier }\end{array}$ & positive & ND & $\begin{array}{l}\text { Diffuse enlargement } \\
\text { of the left testis } \\
\text { with several small } \\
\text { abscesses }\end{array}$ & $\begin{array}{l}\text { Antibiotics, but } \\
\text { orchiectomy was } \\
\text { done due to poor } \\
\text { response to therapy }\end{array}$ \\
\hline $\begin{array}{l}\text { Castillo } \\
\text { Soria et } \\
\text { al. }^{8}\end{array}$ & ND & ND & ND & ND & ND & ND & $\begin{array}{c}\text { Large abscess } \\
\text { causing complete } \\
\text { destruction of testis }\end{array}$ & $\begin{array}{l}\text { Double drug therapy } \\
\text { but orchiectomy } \\
\text { was done due to } \\
\text { complete destruction } \\
\text { of the testis }\end{array}$ \\
\hline $\begin{array}{l}\text { Fernández } \\
\text { Fernández } \\
\text { et al. }{ }^{9}\end{array}$ & ND & ND & $\begin{array}{l}\text { Testicular pain } \\
\text { and swelling }\end{array}$ & $\begin{array}{l}\text { Coexisting } \\
\text { systemic } \\
\text { Brucellosis }\end{array}$ & ND & ND & $\begin{array}{c}\text { Increased } \\
\text { testicular size with } \\
\text { intratesticular } \\
\text { abscess }\end{array}$ & $\begin{array}{l}\text { Antibiotics, nut } \\
\text { orciectomy was done } \\
\text { due to progressive } \\
\text { enlargement of the } \\
\text { abscess }\end{array}$ \\
\hline $\begin{array}{l}\text { Bayram et } \\
\text { al. }^{10}\end{array}$ & ND & ND & ND & ND & positive & $\begin{array}{l}\text { Positive B. } \\
\text { melitensis } \\
\text { from } \\
\text { specimen } \\
\text { culture }\end{array}$ & $\begin{array}{l}\text { Focal hypoechoic } \\
\text { lesion, mean size } 23 \\
\mathrm{~mm}\end{array}$ & $\begin{array}{c}\text { Orchiectomy } \\
\text { as tumour was } \\
\text { suspected, then D } \\
\text { and } R \text { for } 6-8 \text { weeks }\end{array}$ \\
\hline Our case & 36 & 6 weeks & $\begin{array}{l}\text { Left testicular } \\
\text { pain }\end{array}$ & $\begin{array}{l}\text { History of } \\
\text { systemic } \\
\text { Brucellosis } 3 \\
\text { months earlier }\end{array}$ & $\begin{array}{l}\text { Positive } \\
\text { at repeat } \\
\text { dilution of } \\
\text { 1:320 titer }\end{array}$ & Negative & $\begin{array}{l}\text { Multiple anechoic } \\
\text { cystic areas with } \\
\text { internal septation }\end{array}$ & $\begin{array}{c}D, C \text {, and } B \text { for } \\
3 \text { months }\end{array}$ \\
\hline
\end{tabular}


Tahaineh et al.

\section{References}

1. Kaya F, Kocygit A, Kaya C, et al. Brucella testicular abscess case presenting as a testicular mass: Can color Doppler sonography be useful in differentiation? Turk J Emerg Med 2014. http:// dx.doi.org/10.5505 /1304.7361.2014.82698. http://dx.doi.org/10.5505/1304.7361.2014.82698

2. Al-Tawfiq J. Brucellaepididymo-orchitis: A consideration in endemic area. Int Braz J Urol 2006;32:313-5. http://dx.doi.org/10.1590/S1677-55382006000300011

3. Kocak I, Dündar M, Culhaci N, et al. Relapse of brucellosis simulating testis tumor. Int J Urol 2004;11:6835. http://dx.doi.org/10.1111/j.1442-2042.2004.00862.x

4. Akinci E, Bodur H, Cevik MA, et al. A complication of brucellosis: Epididymoorchitis. Int I Infect Dis 2006;10:171-7. http://dx.doi.org/10.1016/i.iij.2005.02.006

5. Koc Z, Turunc T, Boga C. Gonadal brucellar abscess: Imaging and clinical findings in 3 cases and review of the literature. J Clin Ultrasound 2007;35:395-400. http://dx.doi.org/10.1002/icu.20330

6. Yemisen $M$, Karakas E, Ozdemir I, et al. Brucellar testicular abscess: A rare cause of testicular mass. J Infect Chemother 2012;18:760-3. http://dx.doi.org/10.1007/s10156-011-0354-7
7. González Sánchez FJ, Encinas Gaspar MB, Napal Lecumberri S, et al. Brucellar orchiepididymidestis with abscess. Arch Esp Urol 1997;50:289-92.

8. Castillo Soria JL, Bravo de Rueda Accinelli C. Genital brucellosis. A rare cause of testicular abscess. Arch Esp Urol 1994;47:533-6.

9. Fernández Fernández A, Jiménez Cidre $M$, Cruces $F$, et al. Brucellarorchitis with abscess. Actas Urol Esp 1990; 14:387-9

10. Bayram MM, Kervancioğlu R. Scrotal gray-scale and color Doppler sonographic findings in genitourinary brucellosis. J Clin Ultrasound 1997;25:443-7. http://dx.doi.org/10.1002/(SICI) 10970096(199710)25:8<443::AID-JCU6>3.0.C0;2-J

Correspondence: Dr. Sakher Tahaineh, Security Forces Hospital, PO Box. 14799, Makkah 21955, Saudi Arabia; tahineh@yahoo.com 